\title{
Do Diatoms beneath the Greenland Ice Sheet Indicate Interglacials Warmer than Present? ${ }^{1}$
}

\author{
DAVID M. HARWOOD ${ }^{2}$
}

(Received 2 July 1985; accepted in revised form $11 \mathrm{July} \mathrm{1986)}$

\begin{abstract}
Basal sediment debris from the Greenland Ice Sheet was examined with the hope of recovering microfossils that could be used to determine and date changes in ice sheet size through time. Basal debris and debris-laden ice from the lower $18 \mathrm{~m}$ of the Camp Century ice core, northwest Greenland, revealed the presence of common freshwater and rare marine diatoms. These diatoms may have lived in the vicinity of the Camp Century site in the Late Neogene prior to development of the Greenland Ice Sheet. More likely, they lived during a Pleistocene interglacial period, when the volume of ice in the Greenland Ice Sheet was smaller than it is today and the site was ice free. A warmer and/or longer interglacial period than the present Holocene "interglacial" is suggested to explain the large decrease in ice sheet volume.
\end{abstract}

Key words: diatoms, interglacial, Pleistocene, Camp Century ice core, Greenland

RÉSUMÉ. Des dépôts de base de la calotte de glace du Groenland furent examinés dans l'espoir d'y trouver des microfossiles qui pourraient déterminer et dater les variations dans la taille de la calotte à travers les années. Des débris de base et de la glace chargée de sédiments provenant des 18 derniers mètres de la carotte de glace prise au Camp Century dans le nord-ouest du Groenland ont révélé la présence de certaines diatomées d'eau douce communes et $\mathrm{d}$ 'autres diatomées marines rares. Ces diatomées ont peut-être habité la région du Camp Century dans le Néogène supérieur avant la formation de la calotte du Groenland. Il est cependant plus probable qu'elles habitèrent la région lors d'un interglaciaire du Pléistocène, période durant laquelle la calotte était moins volumineuse qu'aujourd'hui et la région était libre de glace. On attribue la grande diminution du volume de glace à une période interglaciaire plus chaude ou prolongée que l'interglaciaire Holocène actuel.

Mots clés: diatomées, interglaciaire, Pléistocène, carotte de glace du Camp Century, Groenland

Traduit pour le journal par Maurice Guibord.

\section{INTRODUCTION}

Interest in debris beneath the Greenland Ice Sheet stems from the recent discovery of marine microfossils in the Plio-Pleistocene Sirius Formation tillite, Transantarctic Mountains, Antarctica (Harwood, 1983, 1985; Webb et al., 1983, 1984). These fossils indicate a complex history of Pliocene deglaciation and Cenozoic marine invasion of East Antarctica. Determining whether a similar history could be deciphered from debris near the base of the Greenland Ice Cap was the initial goal of the present study.

The Greenland Camp Century ice core $\left(77^{\circ} 10^{\prime} \mathrm{N}, 61^{\circ} 08^{\prime} \mathrm{W}\right.$; $1885 \mathrm{~m}$ asl) (Fig. 1) reached a total depth of $1391 \mathrm{~m}$. This project was the first to reach the base of an ice sheet and retrieve basal debris. More than 300 layers of alternating clear ice and debris-laden ice are present in the lowest $16 \mathrm{~m}$ of the core (Herron and Langway, 1979). These layers range in size between $<1 \mathrm{~mm}$ and $>1 \mathrm{~m}$, with pebbles and fragments (clasts) of sedimentary rock and compact mud up to $2-3 \mathrm{~cm}$ in diameter. Also recovered was $3.55 \mathrm{~m}$ of frozen glacial debris at the base of the core (Hansen and Langway, 1966).

\section{RESULTS}

Four samples of silty ice (numbers $1,2,3,4$ ) and two samples of unconsolidated basal debris $(5,6)$ were examined for microfossils (Table 1). Rich freshwater diatom assemblages and chrysophyte cysts were recovered from samples 1,5 and 6 (Table 2, Figs. 2-4). The majority of the freshwater diatoms are extant species with widespread distribution in the arctic region. The freshwater floral assemblages from samples 1 and 6 are similar, although sample 6 was more diverse. Sample 5 contained fewer and less well-preserved diatoms.
TABLE 1. Sample descriptions

\begin{tabular}{|c|c|c|c|c|}
\hline Sample \# & ID number & Sample size & Core depth & Microfossils \\
\hline 1 & 1048-B3 & $50.4 \mathrm{cc}$, ice & $1358.8 \mathrm{~m}$ & $\begin{array}{l}\text { common, well- } \\
\text { preserved fresh- } \\
\text { water diatoms and } \\
\text { Chrysophyte cysts }\end{array}$ \\
\hline 2 & $1051-C 2$ & $37.5 \mathrm{cc}$, ice & $1363.2 \mathrm{~m}$ & none recovered \\
\hline 3 & 1052-B1 & $112 \mathrm{cc}$, ice & $1364.8 \mathrm{~m}$ & none recovered \\
\hline 4 & 1056-B3 & $48 \mathrm{cc}$, ice & $1370.7 \mathrm{~m}$ & none recovered \\
\hline 5 & 1059 & $\begin{array}{l}\approx 5 \mathrm{cc}, \text { loose } \\
\text { sediment }\end{array}$ & $1373.0 \mathrm{~m}$ & $\begin{array}{l}\text { rare, poorly } \\
\text { preserved fresh- } \\
\text { water diatoms and } \\
\text { Chrysophyte cysts }\end{array}$ \\
\hline \multirow[t]{2}{*}{6} & $1060 \mathrm{~A}$ & $\begin{array}{l}\approx 5 \mathrm{cc}, \text { loose } \\
\text { sediment }\end{array}$ & $1376.6 \mathrm{~m}$ & $\begin{array}{l}\text { common, well- } \\
\text { preserved fresh- } \\
\text { water diatoms and } \\
\text { Chrysophyte cysts }\end{array}$ \\
\hline & & & & $\begin{array}{l}\text { rare marine } \\
\text { diatoms, a dino- } \\
\text { flagellate, sponge } \\
\text { spicules, and } \\
\text { pollen }\end{array}$ \\
\hline
\end{tabular}

Marine microfossils, including marine diatoms, a dinoflagellate and sponge spicules, and pollen were recovered from sample 6. Samples 2, 3 and 4 contained no microfossils. Microscope slides of this material are on file with the Diatom Herbarium, Academy of Natural Sciences, in Philadelphia.

\section{AGE OF THE BASAL DEBRIS AND FRESHWATER DIATOMS}

An ice record of approximately 125000 years is estimated for

\footnotetext{
${ }^{1}$ Contribution No. 562 of the Institute of Polar Studies, The Ohio State University

${ }^{2}$ Institute of Polar Studies and Department of Geology and Mineralogy, The Ohio State University, Columbus, Ohio 43210, U.S.A.

CThe Arctic Institute of North America
} 


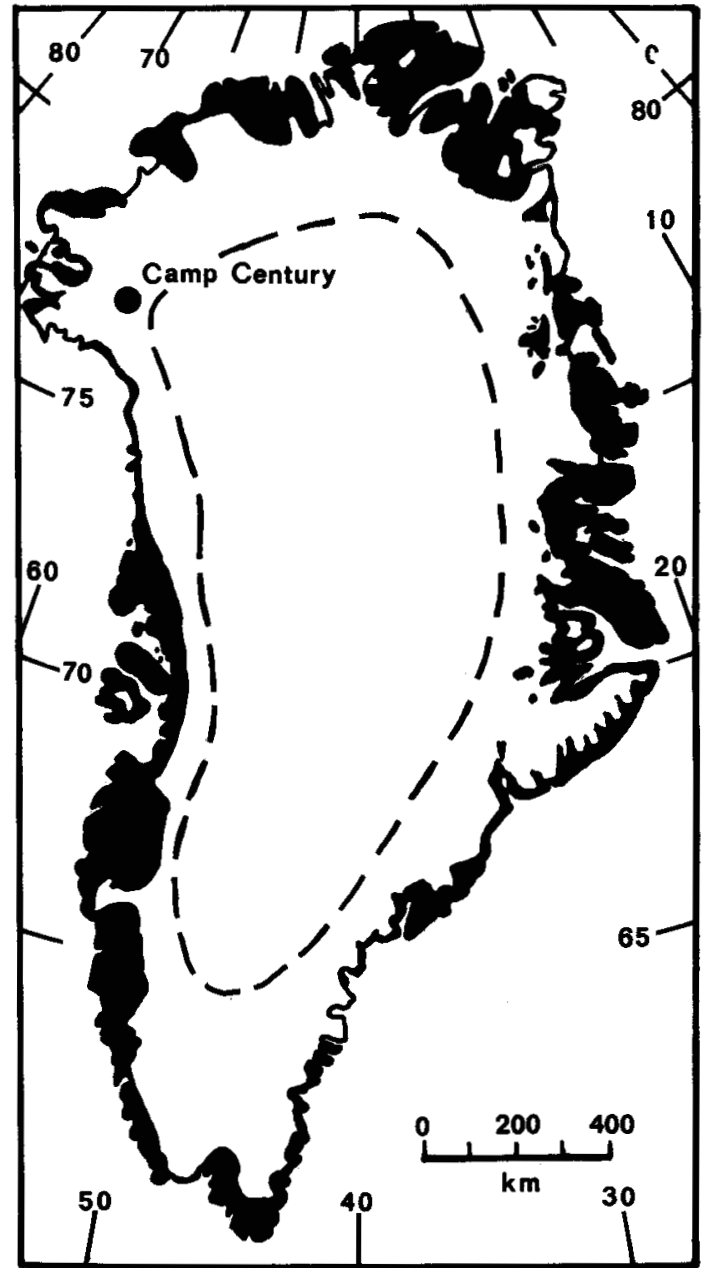

FIG. 1. Location of the Camp Century ice core, Greenland. Dashed line represents estimated maximum dimension of interglacial ice sheet during growth of freshwater diatom assemblages recovered from Camp Century ice core:-

the Camp Century ice core (Dansgaard et al., 1969). This age could be underestimated if a layer of water existed at the base of the ice sheet at any time during the past (Weertman, 1976). Assuming the presence of basal water, Herron and Langway (1979) suggest the base of the Camp Century ice core could be 425000 years old. Thus, the basal debris-laden ice examined in this study may be even older.

Precise dating of these assemblages is not possible. However, a maximum age for these sediments can be inferred from the recovery of marine diatom Hemidiscus cueniformis (Fig. 3:1), which ranges from late-middle Miocene $(\approx 12$ million yr) to Recent in the North Atlantic Region (Baldauf, 1984). It is likely that the marine diatoms, dinoflagellates and sponge spicules were reworked into a freshwater setting by wind transport from the coast or local fjords. Additional support for wind transport is indicated by characteristic aeolian sands reported in the Camp Century basal debris by Whalley and Langway (1980). Erosion and transport of an inland marine deposit by ice is another mechanism that may account for the presence of these marine microfossils. Even though the marine diatoms are reworked, the 12 million yr age still represents the maximum age for these sediments.

The basal sediments and freshwater diatoms may indicate preglacial conditions prior to the development of the Greenland

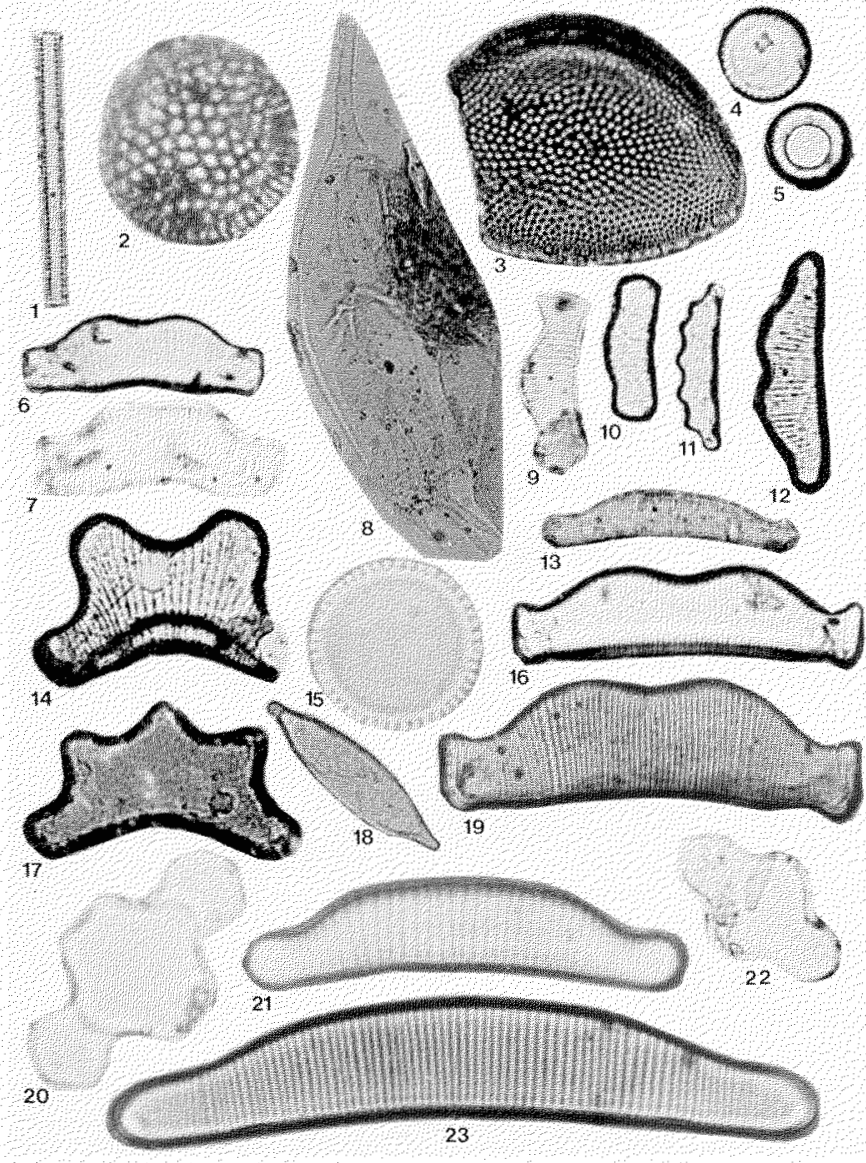

FIG. 2. (1) Thalassiothrix sp., marine diatom, $x 1000$, sample 6. (2) Hemidiscus cueniformis Wallich, marine diatom, $x 1000$, sample 6. (3) Coscinodiscus marginatus Ehrenberg, marine diatom, $\mathrm{x} 700$, sample 6. (4,5)Melosiradistans (Ehrenberg) Kutzing, $x 1000$, sample 6. (6,7) Eunotia praerupta var., $x 1000$, sample 6. (8) Marine dinoflagellate, $x 500$, sample 6. (9) Eunotia cf. exigua (Brébisson) Rabenhorst, x1000, sample 6. (10) Eunotia praerupta Ehrenberg v. curta Grunow, x1000, sample 6. (11) Eunotia trinacria (Krasske) Grunow, $\mathrm{x} 1000$, sample 6. (12) Eunotia bidentula W. Smith, x1000, sample 6. (13) Eunotia praerupta Ehrenberg, x1000, sample 6. (14) Eunotia papilio (Grunow) Hustedt, $\mathrm{x} 1000$, sample 6. (15) Cyclotella sp. x700, sample 1. $(16,19)$ Eunotia praerupta Ehrenberg v. bidens (W. Smith) Grunow, 16. $\times 700 ; 19 . \times 1000$, sample 6. (17) Eunotia triodon Ehrenberg, x1000, sample 6. (18) Stauroneis sp. (girdle), $\times 1000$, sample 6. (20) Tetracyclus emarginatus (Ehrenberg) Smith, $x 1000$, sample $6 . \quad(21,23)$ Eunotia monodon Ehrenberg, x1000, sample 1. (22) Tetracyclus lacustris Ralfs, x1000, sample 1.

Ice Sheet. The initiation of Northern Hemisphere glaciation is presently dated at 2.4 million yr ago (Shackleton et al., 1984). The freshwater flora and basal debris must be older than 2.4 million yr if they pre-date ice sheet development.

Alternatively, the sediments and freshwater flora may indicate Pleistocene interglacial conditions with a lesser ice volume than exists today. A receding ice front would expose the Camp Century site. In keeping with this potential scenario, the age of the flora must lie between 2.4 million yr and the oldest age suggested for Camp Century ice (425 000 or $125000 \mathrm{yr}$ ), i.e., Pliocene-late Pleistocene. Support for a Pleistocene age of this material comes from the modern appearance of the diatom flora (in that most species are extant) and the soft (non-indurated) and muddy nature of the clasts recovered in ice sample 1 . It is expected that Miocene-Pliocene lake sediments would be more indurated. Future advancement of freshwater diatom biostratigraphy and/or the recovery of additional marine microfossils 
TABLE 2. Microfossils recovered from Camp Century basal-ice and basal-debris

\begin{tabular}{lll}
\hline \hline Samples & Age \\
\hline A. & Marine components & \\
\hline 6 & Coscinodiscus marginatus Ehrenberg & non-diagnostic \\
6 & Hemidiscus cueniformis Wallich & Miocene to \\
& & Recent \\
6 & Thalassiothrix sp. & non-diagnostic \\
6 & dinoflagellate & -
\end{tabular}

B. Freshwater diatoms

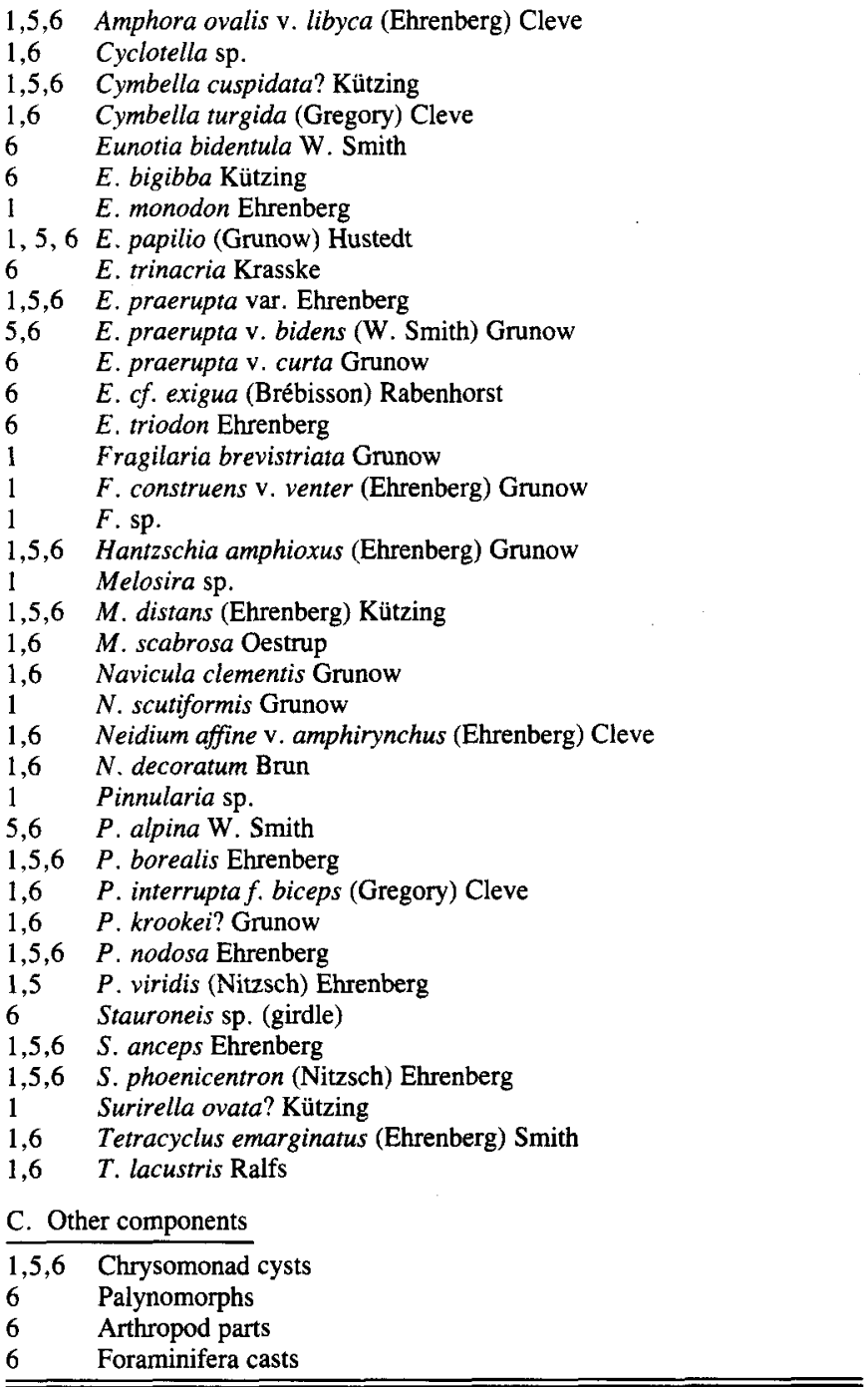

from this ice core may resolve which of the above scenarios is correct. At the present time the Pleistocene age appears more likely.

\section{DISCUSSION}

Herron and Langway (1979) conclude that the source of debris in the ice is from the base of the ice sheet rather than from surficial debris and that some type of freezing-on process led to the incorporation of debris within the ice. Their conclusions are based on: (1) large particle sizes relative to atmospherically transported dust, (2) greater volume of debris relative to atmospherically transported debris, (3) grain surface features indicating glacial abrasion and (4) similarity of mineralogical composition through the debris-laden ice zone and to the basal sediments. Adding to this list, the similarity of freshwater diatom assemblages from the debris-laden ice (sample 1) to that from the basal debris (sample 6) suggests the source for the diatoms in the debris-laden ice is diatom-bearing debris at the base of the ice sheet. The source of this material and the horizontal distance traveled from source at the bed to the present position at Camp Century is unknown. A likely source area, where lakes may have existed during preglacial or interglacial times, is the broad, low elevation region east of Camp Century (Weidick, 1975).

Because the well-preserved microfossils survived the rigors of basal and sub-ice stress, these results illustrate the potential of

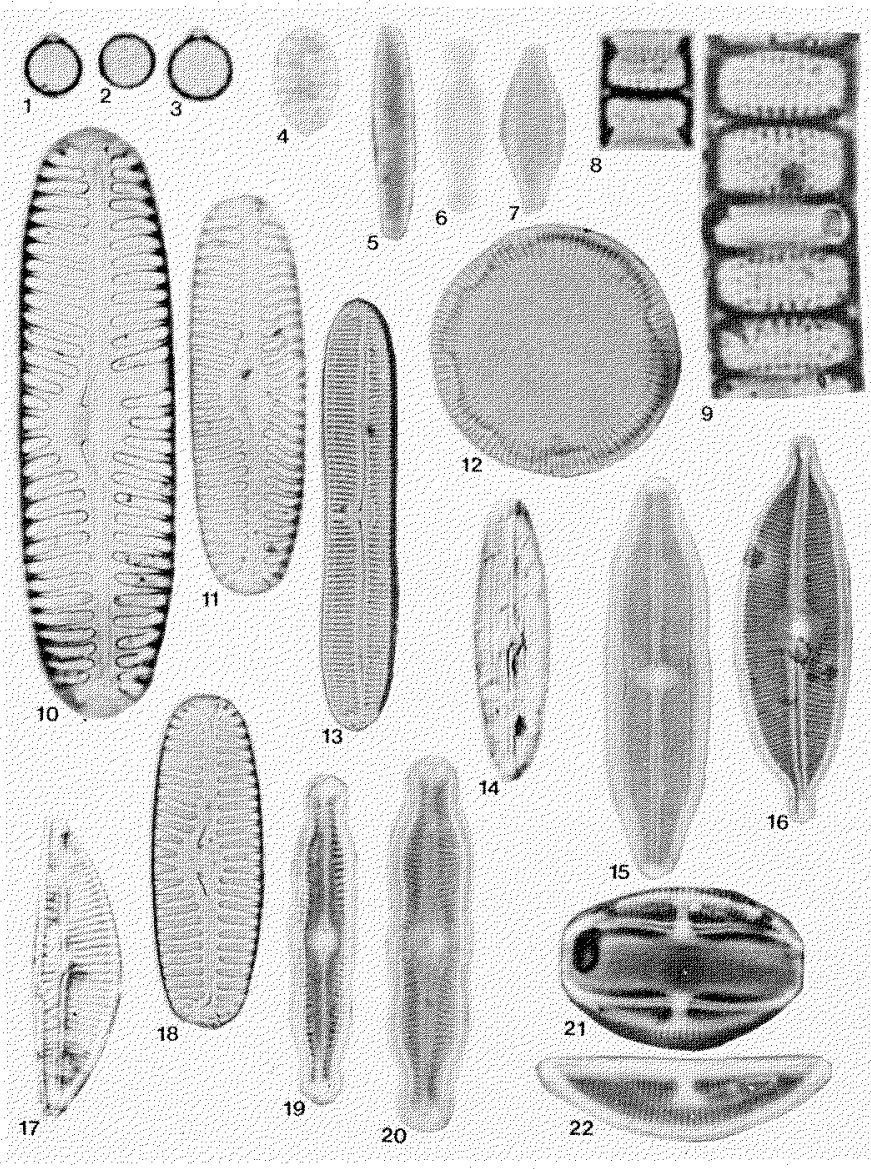

FIG. 3. (1-3) Chrysophyte cysts, x1000, sample 6. (4) Fragilaria construens v. venter (Ehrenberg) Grunow, x2000, sample 1. (5) Fragilaria sp., x2000, sample 1. (6) Pinnularia krookei? Grunow, $\mathrm{x} 2000$, sample 1. (7) Fragilaria brevistriata Grunow, $\times 2000$, sample 1. (8) Melosira sp., x1000, sample 1. (9) Melosira distans (Ehrenberg) Kützing, x2000, sample 1. (10) Pinnularia alpina W. Smith, x1000, sample 6. (11) Pinnularia borealis? Ehrenberg, x1000, sample 1. (12) Melosira scabrosa Oestrup, x1000, sample 1 . (13) Pinnularia viridis? (Nitzsch) Ehrenberg, x1000, sample 1. (14) Neidium decoratum Brun, Nomarski interference illumination, $x 700$, sample 6 . (15) Neidium affine v. amphirynchus (Ehrenberg) Cleve, x1000, sample 1. (16) Cymbella cuspidata? Kutzing, $x 700$, sample 1 . (17) Cymbella turgida (Gregory) Cleve, Nomarski interference illumination, x1000, sample 6. (18) Pinnularia borealis Ehrenberg, $\times 1000$, sample 1. (19) Pinnularia nodosa Ehrenberg, x700, sample 1. (20) Pinularia interrupta f. biceps (Gregory) Cleve, $x 700$, sample 1. $(21,22)$ Amphora ovalis (Kutzing) Kutzing v. libyca (Ehrenberg) Cleve. 21, x1000, sample 1;22. x1000, sample 6. 


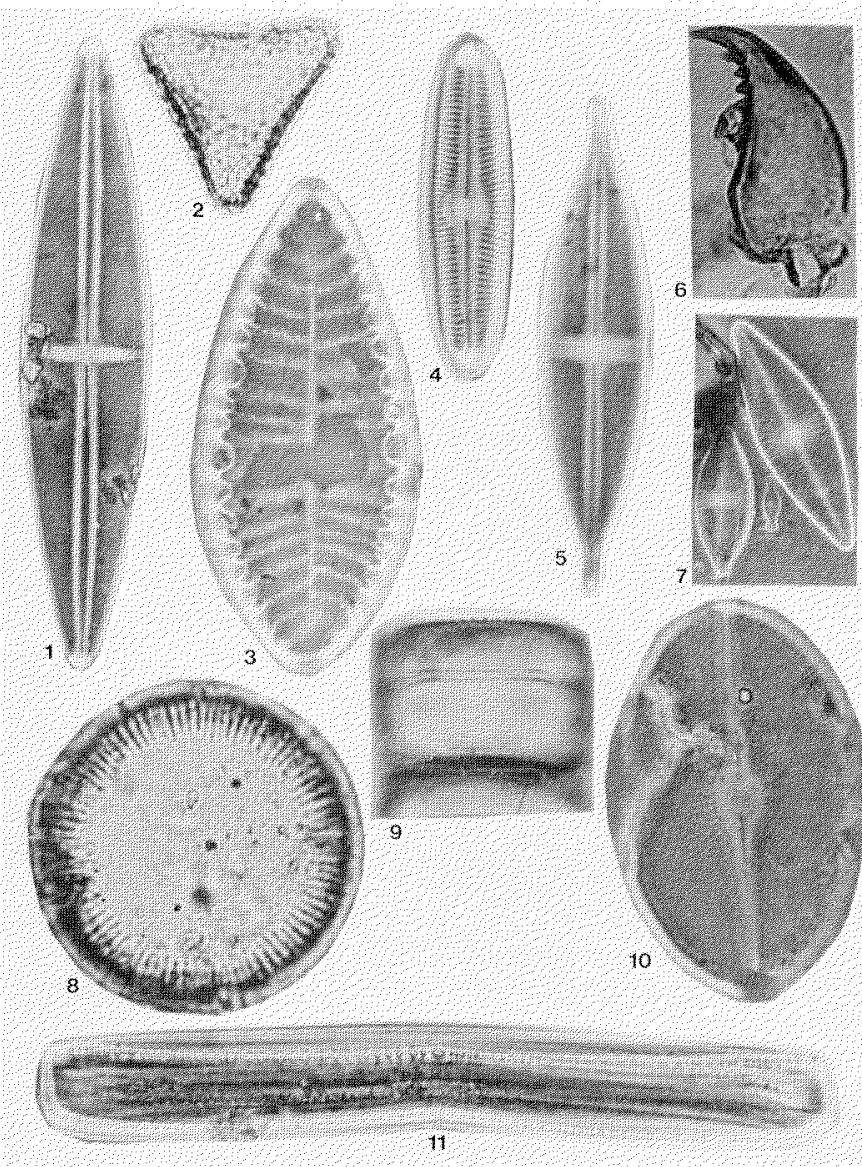

FIG. 4. (1) Stauroneis phoenicentron (Nitzsch) Ehrenberg, x700, sample 1. (2) Palynomorph, x700, sample 6. (3) Surirella ovata? Kutzing, x1000, sample 1. (4) Pinnularia sp., $\times 700$, sample 1. (5) Stauroneis anceps Ehrenberg, x700, sample 1. (6) Arthropoda - insect part, x500, sample 6. (7) Navicula clementis Grunow and Pinnularia krookei? Grunow, x700, sample 1. $(8,9)$ Melosira scabrosa Oestrup, 8 . valve view, x1000, sample 6; 9. girdle view, x700, sample 1. (10) Navicula scutiformis Grunow, x700, sample 1. (11) Hantzschia amphioxus (Ehrenberg) Grunow, x700, sample 6.

microfossils in dating glacial events. The lowest $10 \mathrm{~m}$ of core are highly deformed. The absence of diatoms in samples 3 and 4 , and their reduced abundance and poor presentation in sample 5 , all within this zone, may reflect dilution by horizontal shearing of diatom-bearing clasts in this high shear zone. In contrast, the well-preserved floras in samples 1 (above) and 6 (below) this zone appear unaffected by basal shear. Alternatively, the vertical distribution of diatoms in the ice core may reflect a patchy distribution of diatom-bearing sediments upstream or else horizontal variation in the mechanism of debris entrainment at the bed.

The subglacial topography below the Camp Century site is reasonably level, situated approximately $500 \mathrm{~m}$ above sea level for at least $50 \mathrm{~km}$ to the north, south and west (Robin et al., 1969). The recovery of freshwater diatom assemblages and only a few, probably windblown, marine diatoms is not surprising. The Camp Century site would not be covered by marine waters during preglacial interglacial times as the site is situated $\sim 600 \mathrm{~m}$ above sea level. A $200 \mathrm{~m}$ knoll is situated $20 \mathrm{~km}$ to the east of Camp Century. Beyond this lies a vast plain with a subglacial elevation $400 \mathrm{~m}$ lower than Camp Century. This region is a likely source for the freshwater diatom assemblages.

This paper illustrates the potential of using marine and freshwater microfossils, either recycled or in situ, to date interglacial events and thus establish a chronology of glacial advance and retreat. Even if the microfossils are eroded by ice and redeposited at some distance from the place of original deposition, they are still able to provide some age control. The glacial event responsible for their erosion and transport must post-date the age of the deposits, i.e., the event must be younger than the age of the youngest microfossils.

Diatoms are apparently able to withstand the strain of subglacial and englacial processes associated with large ice sheets. Their small size and solid construction favor their preservation. Low overall microfossil abundance in glacial deposits, however, is the primary factor limiting this method of dating glacial and interglacial events.

\section{CONCLUSION}

The recovery of non-marine diatoms from basal debris in the Camp Century ice core indicates major variation in the size of the Greenland Ice Sheet. These diatoms suggest the northwest corner of Greenland, and probably much more of the continent, was exposed during an episode of ice retreat associated with a Pleistocene interglacial period. Although the modern nature of the diatom assemblages and non-indurated condition of diatombearing mud clasts support a Pleistocene age, the diatoms may reflect late Pliocene preglacial conditions.

In order to expose the Camp Century site during a Pleistocene interglacial and maintain an equilibrium ice profile for the resulting ice sheet, a reduction of at least one-third to one-half of the present ice sheet volume must have occurred (Fig. 1). This reduction implies that previous interglacials were warmer and/or of longer duration than the present Holocene "interglacial," to account for the lesser volume of ice. Unfortunately, the limited biostratigraphic control available today for freshwater diatoms prevents determining which Pleistocene interglacial is represented or whether the diatom assemblages reflect preglacial conditions. Future work on diatoms from this and other ice cores, as well as advancements in freshwater diatom biostratigraphy, may provide a better age for these assemblages and events.

\section{ACKNOWLEDGEMENTS}

The author thanks Peter N. Webb for suggesting this study, R. Patrick and J. Platt Bradbury for assistance with freshwater diatom identification and ecological interpretations, Ellen M. Thompson and John Bolzam for critical review, and the Ice Core Storage Facility, SUNY at Buffalo and National Science Foundation for providing sample material. This research was supported by NSF grant DPP-8315553 to P.N. Webb and GSA Research Grant to D. Harwood.

\section{REFERENCES}

BALDAUF, J.G. 1984. Cenozoic diatom biostratigraphy and paleoceanography of the Rockall Plateau region, North Atlantic, Deep Sea Drilling Project Leg 81. Roberts, D.G., Schnitker, D., eds. Initial Reports of the Deep Sea Drilling Project 81. Washington, D.C.: U.S. Government Printing Office. 439-478.

DANSGAARD, W., JOHNSEN, S.J., MOLLER, J. 1969. One thousand centuries of climatic record from Camp Century on the Greenland Ice Sheet. Science 166(3903):377-381.

HANSEN, B.L., and LANGWAY, C.C., Jr. 1966. Deep core drilling in ice and core analysis at Camp Century, Greenland, 1961-1966. Antarctic Journal of the U.S. 1(5):207-208. 
HARWOOD, D.M. 1983. Diatoms from the Sirius Formation, Transantarctic Mountains. Antarctic Journal of the U.S. 18(5):98-100.

1985. Late Neogene climatic fluctuations in the high-southern latitudes: implications of a warm Gauss and deglaciated Antarctic continent. South African Journal of Science 81:239-241.

HERRON, S., and LANGWAY, C.C., Jr. 1979. The debris-laden ice at the bottom of the Greenland Ice Sheet. Journal of Glaciology 23(89):193-207.

ROBIN, G. de Q., EVANS, S., and BAILEY, I.T. 1969. Interpretation of radio echo soundings in polar ice sheets. Philosophical Transactions of the Royal Society of London, Series B, 265:437-505.

SHACKLETON, N.J., BACKMAN, J., ZIMMERMAN, H., KENT, D.V., HALL, M.A., ROBERTS, D.G., SCHNITKER, D., BALDAUF, J.G., DESPRAIRIES, A., HOMRIGHAUSEN, R., HUDDLESTUN, P. , KEENE, J.B., KALTENBACK, D., KRUMSIEK, K.A.O., MORTON, A.C., MURRAY, J.W., and WESTBERG-SMITH, J. 1984. Oxygen isotope calibration of the onset of ice-rafting and history of glaciation in the North Atlantic region. Nature 307:620-623.
WEBB, P.N., HARWOOD, D.M., MCKELVEY, B.C., MERCER, J.H., STOTT, L.D. 1983. Late Neogene and older Cenozoic microfossils in high-elevation deposits of the Transantarctic Mountains: evidence for marine sedimentation and ice volume variation on the East Antarctic Craton. Antarctic Journal of the U.S. 18(5):96-97.

1984. Cenozoic marine sedimentation and ice volume variation on the East Antarctic Craton. Geology 12(5):287-291.

WEERTMAN, J. 1976. Sliding-no-sliding zone effect and age determination of ice-cores. Quaternary Research 6(2):203-207.

WEIDICK, A. 1975. A review of Quaternary investigations in Greenland. Institute of Polar Studies, Ohio State University, Report No. 55. $161 \mathrm{p}$.

WHALLEY, W.B., and LANGWAY, C.C., Jr. 1980. A scanning electron microscope examination of subglacial quartz grains from Camp Century core, Greenland - a preliminary study. Journal of Glaciology 25(91):125-131. 